Tersedia online di: http://ejournal-balitbang.kkp.go.id/index.php/bawal
e-mail:bawal.puslitbangkan@gmail.com
BAWAL wIDYA RISET PERIKANAN TANGKAP
Volume 11 Nomor 1 April 2019
p-ISSN: 1907-8226
e-ISSN: 2502-6410
BAWAL
Nomor Akreditasi Kementerian RISTEKDIKTI: 21/E/KPT/2018

\title{
STUDI ASPEK REPRODUKSI IKAN KEMBUNG LELAKI (Rastrelliger kanagurta, Cuvier 1817) PADA MUSIM PERALIHAN DI SELAT MADURA
}

\section{STUDY OF REPRODUCTIVE ASPECT OF INDIAN MACKEREL (Rastrelliger kanagurta, Cuvier 1817) AT TRANSITIONAL SEASON IN MADURA STRAIT}

\author{
Evi Susanti $^{* 1}$, Arief Setyanto ${ }^{1}$, Daduk Setyohadi ${ }^{1}$ dan Irwan Jatmiko ${ }^{2}$ \\ ${ }^{1}$ Fakultas Perikanan dan Ilmu Kelautan, Universitas Brawijaya, Jl. Veteran No.16, Malang, Jawa Timur 65145, Indonesia \\ ${ }^{2}$ Loka Riset Perikanan Tuna, Denpasar-Bali, J1. Mertasari No.140, Sidakarya, Denpasar, Bali 80224, Indonesia \\ Teregistrasi I tanggal: 03 AGustus 2018; Diterima setelah perbaikan tanggal: 20 Januari 2020; \\ Disetujui terbit tanggal: 22 Januari 2020
}

\begin{abstract}
ABSTRAK
Ikan kembung lelaki (Rastrelliger kanagurta) merupakan salah satu jenis ikan pelagis kecil yang bermanfaat untuk memenuhi kebutuhan akan protein masyarakat, dan juga dapat digunakan sebagai umpan dalam perikanan rawai tuna (tuna long line). Kebutuhan yang tinggi akan jenis ikan ini dapat menimbulkan tekanan terhadap populasi ikan ini sehingga menyebabkan penangkapan yang berlebih. Dalam mengelola sumberdaya ikan diperlukan informasi mengenai biologi reproduksi dan aspek biologi lainnya. Salah satu aspek biologi yang terkait dengan informasi reproduksi adalah tingkat kematangan gonad. Dalam studi ini menganalisis hubungan panjang berat, nisbah kelamin, tingkat kematangan gonad (TKG), indeks kematangan gonad (IKG), dan hubungan antara IKG dengan berat ikan kembung lelaki. Pengamatan TKG dilakukan secara morfologi dan histologi. Pengambilan contoh ikan dilakukan di Tempat Pelelangan Ikan Mayangan, Probolinggo, Jawa Timur, selama bulan Februari sampai April 2018. Hasil analisa hubungan panjang berat menunjukkan bahwa ikan kembung lelaki memiliki pola pertumbuhan allometrik positif, nisbah kelamin ikan kembung lelaki jantan dan betina yaitu 87\%:13\% (6:1), Hasil pengamatan tingkat kematangan gonad secara morfologi pada 400 ikan contoh menunjukkan dalam keadaan belum matang gonad (tingkat kematangan I, II, III), pengamatan gonad secara histologi pada 8 ikan contoh menujukkan dalam keadaan tingkat kematangan gonad III dan IV. Ukuran diameter telur pada tingkat kematangan gonad III antara 280,91 -314,74 $\mu \mathrm{m}$ dengan rerata 296,78 $\mu \mathrm{m}$ dan pada tingkat kematangan gonad IV antara 287,99-315,31 $\mu \mathrm{m}$ dengan rerata $303,89 \mu \mathrm{m}$ dengan nilai fekunditas antara 4.863,96-28.255,32 butir telur. Indeks kematangan gonad pada bulan Februari, Maret, April adalah 1,78, 1,32, dan 0,55. Analisa korelasi antara hubungan berat dengan IKG mempunyai hubungan yang signifikan dengan tingkat keeratan yang rendah.
\end{abstract}

Kata Kunci: Ikan kembung lelaki; kematangan gonad; Histologi; Mayangan Probolinggo

\section{ABSTRACT}

Indian mackerel (Rastrelliger kanagurta) is one of the small pelagic fish that is useful a need of protein requirement of the people while, and can also be used as bait in (tuna long line). High demand for this fish can cause pressure on this fish population, then cause overfishing. In managing fish resources, information about reproductive biology and other aspects of biology is needed. One aspect of biology related to reproductive information is the level of gonad maturity. In this study analyzed the relationship of leng weight relationship, sex ratio, gonad maturity level (GML), gonado somatic index (GSI) and relationship of GSI with weight of the indian mackerel. Fish sampling was conducted at Fish Auction Hall of Mayangan, Probolinggo, East Java during February to April 2018. The analysis result of length weight relationship show that indian mackerel has a positive allometric growth pattern, sex ratio of male and female is $87 \%: 13 \%(6: 1)$. Morphological observation of gonad maturity level at 400 fish samples showed that the gonads were immature (gonad maturity levels I, II, III), histologic gonad observation on 8 fish samples showed in maturity state of gonad III and IV. The size of egg diameter at maturity level of gonad III between 280.91 -314.74 im with an average of 296.78 im and at maturity 
level of gonad IV between 287.99-315.31 im with an average of 303.89 ìm with a fecundity value between 4,863.96-28,255.32 eggs. Index of gonad maturity in February, March, April was 1.78, 1.32, and 0.55. Correlation analysis between the weight with GSI has a significant relationship but has a low level of closeness.

\section{Keywords: Indian mackerel; Gonad maturity; Histology; Mayangan Probolinggo}

\section{PENDAHULUAN}

Ikan kembung lelaki atau disebut banyar di Selat Madura mempunyai sebaran yang luas karena mempunyai sifat bermigrasi. Ikan ini mempunyai nilai gizi yang tinggi dan nilai ekonomis menengah, sehingga menyebabkan nelayan terus menerus melakukan penangkapan untuk memenuhi permintaan konsumen domistik yang tinggi. Kisaran harga di pasaran yaitu Rp25.000-Rp35.000 per kg tergantung ukuran ikannya. Alat penangkapan ikan yang digunakan nelayan untuk menangkap ikan kembung adalah mini purse seine, dengan lama trip harian (one day fishing) sampai tiga hari. Dikhawatirkan status stok ikan ini akan terus menurun akibat tangkapan yang berlebih (over exploited) yang dilakukan secara terus menerus (Zamroni \& Suwarso, 2011).

Dalam mengelola sumber daya ikan pelagis berbasis stok, sifat-sifat biologi ikan, serta lingkungannya perlu diketahui diantaranya informasi mengenai aspek reproduksi. Tingkat kematangan gonad merupakan salah satu aspek yang perlu dipelajari, sehingga target dalam memanfaatkan suatu sumber daya ikan, dan pengelolaannya dapat dilakukan secara lebih hati-hati agar sumber daya dapat terjaga (Zamroni \& Suwarso, 2011).

Penentuan tingkat kematangan gonad dapat dilakukan secara morfologi dan histologi. Histologi adalah ilmu yang mempelajari tentang struktur jaringan secara detail menggunakan mikroskop pada jaringan yang dipotong tipis. Menggunakan organ reproduksi (gonad). Informasi yang didapat berupa tingkat kematangan gonad dan ukuran diameter telur dari analisis preparat gonad. Analisis histologi memberikan hasil yang akurat tentang status reproduksi ikan (Schaefer, 2001). Beberapa jenis ikan yang pernah diteliti menggunakan metode histologi yaitu ikan tuna, cakalang, lisong, kembung perempuan, kakap, kerapu sunu dan masih banyak lagi (Jatmiko, 2015).

Tulisan ini bertujuan untuk memberikan informasi mengenai aspek biologi reproduksi ikan kembung lelaki (R. kanagurta) di perairan Selat Madura, dan diharapkan dapat memberikan kontribusi dalam penyusunan opsi pengelolaan sumberdaya perikanan agar tercipta sumberdaya perikanan yang lestari dan berkelanjutan.

\section{BAHANDANMETODE}

Jenis ikan yang diamati dalam penelitian ini adalah ikan kembung lelaki (R. kanagurta) (Gambar 1) yang didaratkan di TPI Mayangan, Probolinggo, Jawa Timur yang diasumsikan mewakili populasi ikan dari perairan Selat Madura (Gambar 2), selama bulan Februari sampai April 2018.

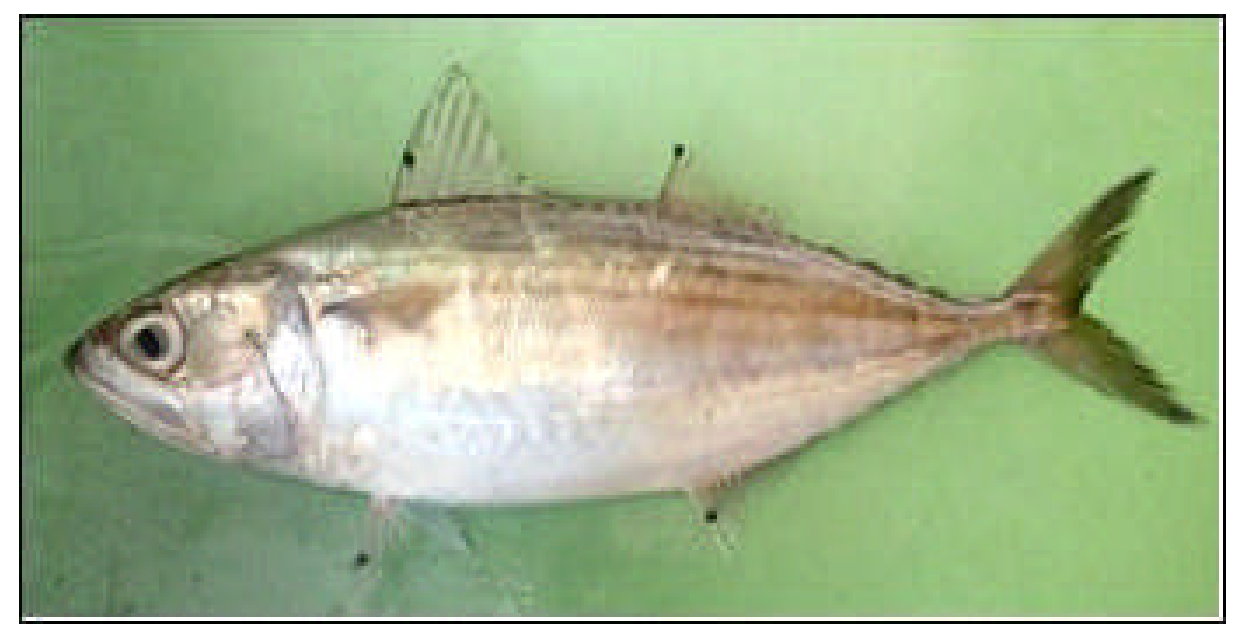

Gambar 1. Ikan kembung lelaki (Rastreliger kanagurta Cuvier, 1817).

Figure 1. Indian mackerel (Rastrelliger kanagurta Cuvier, 1817). 


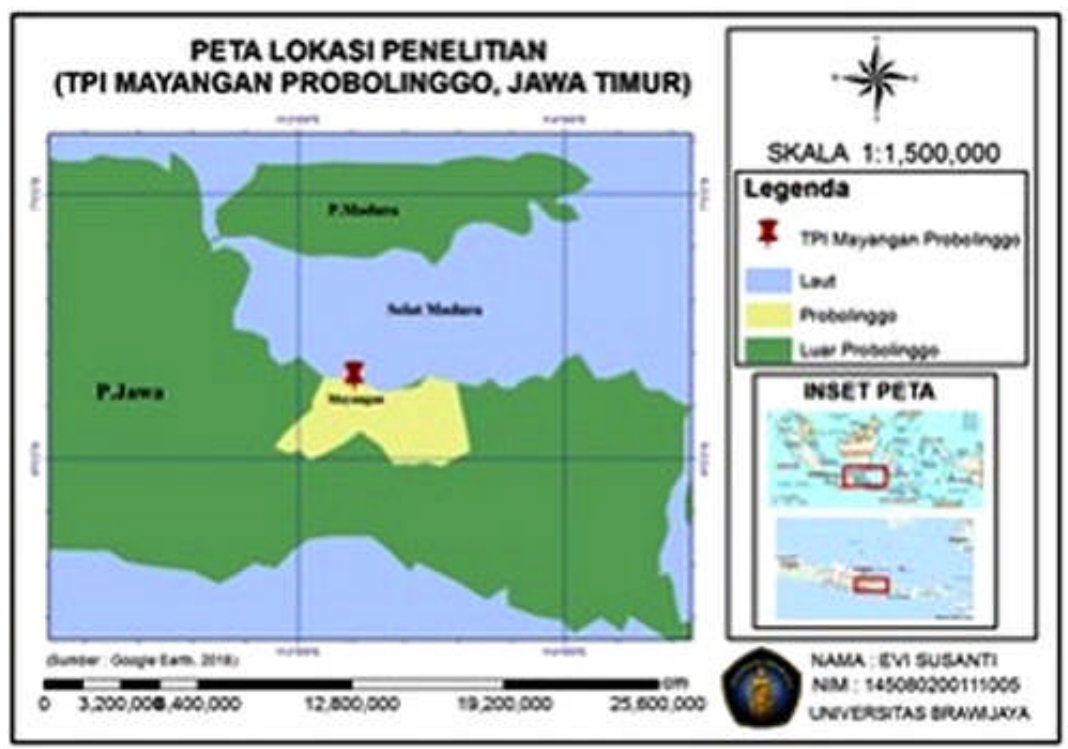

Gambar 2. Peta menunjukan lokasi pengambilan sampel ikan.

Figure 2. The map shows the location of fish sampling.

Dalam pelaksanaannya, metode pengambilan sampel menggunakan teknik simple random sampling. Pengambilan sampel dilakukan sebanyak 4 kali selama penelitian pada bulan Februari-April 2018 dengan jumlah sampel sebanyak 100 ekor setiap kali sampling, sehingga totalnya sebanyak 400 ekor. Ikan kembung lelaki/banyar yang dijadikan sampel merupakan hasil tangkapan mini purse seine yang beroperasi di perairan Selat Madura.

Penentuan tingkat kematangan gonad menggunakan dua metode yaitu morfologi dan histologi. Penentuan tingkat kematangan gonad secara morfologi berdasarkan 5 skala menurut Schaefer \& Orange (1956) dan (Zamroni \& Suwarso, 2011) untuk ikan betina dan jantan (Lampiran 3 dan Lampiran 4). Penentuan tingkat kematangan gonad secara histologi menggunakan acuan dari Farley \& Davis (1999) yang membagi menjadi 5 tingkatan histologis yaitu. Unyolked stage, early yolked stage, advanced yolked stage, migratory nucleus stage, hydrated stage. Langkahlangkah pembuatan preparat histologi menurut Mujimin (2005) sebagai berikut: Pengambilan gonad, fiksasi menggunakan larutan formalin $10 \%$ selama 24 jam, dehidrasi (Alkohol 70\% I, Alkohol 70\% II, Alkohol 90\% I, Alkohol 90\% II, Alkohol absolut I, Alkohol absolut II) masing-masing selama 45 menit, penjernihan (clearing) (Xylol I, Xylol II) masing-masing selama 45 menit, embedding dan blocking (parafin cair), pengirisan (sectioning) menggunakan microtome dengan ketebalan 4-6 mikron dan peletakan pada gelas objek, pewarnaan (staining) menggunakan Hematoxylin-Eosin (HE) dan penutupan.

Analisis hubungan panjang berat menggunakan persamaan (Sparre \& Venema, 1999):

$\mathrm{W}=\mathrm{a}^{*} \mathrm{~L}^{\mathrm{b}}$ di mana:

$\mathrm{W}=$ berat $(\mathrm{g})$

$\mathrm{L}=$ panjang ikan $(\mathrm{cm})$

a $=$ intercept

$\mathrm{b}=$ faktor kondisi

Analisis nisbah kelamin menggunakan persamaan (Syahriani et al., 2015) yaitu:

$$
N k-\frac{M}{F}
$$

di mana:

$\mathrm{Nk}$ : nisbah kelamin

M : jumlah total ikan jantan (individu)

$\mathrm{F}$ : jumlah total ikan betina (individu)

Pengukuran diameter telur dilakukan dengan menggunakan aplikasi Image Raster 3 dengan rumus seperti disampaikan Putri (2012) seperti berikut:

$$
D=\frac{(a+b)}{2}
$$

di mana :

D : diameter telur

a : jarak panjang telur

b : lebar telur

Perhitungan fekunditas dilakukan dengan mengambil satu bagian sub sampel gonad yaitu pada bagian tengah gonad dengan berat 0,5 gram. Pendugaan fekunditas menggunakan acuan rumus dari Kusmini et al. (2016), yaitu: 
$F=\frac{G}{g} X x$

di mana :

$\mathrm{F}$ : fekunditas

$\mathrm{G}$ : bobot gonad (g)

$\mathrm{g}$ : bobot sub sampel $(\mathrm{g})$

$\chi:$ Jumlah telur dalam sub sampel

Perhitungan nilai indeks kematangan gonad/ Gonado Somatic Index (GSI) menggunakan persamaan yang bersumber dari IOTC (2010), yaitu:

$G S I=\frac{W g}{W} 10^{2}$

di mana :

GSI : gonado somatic index

$\mathrm{Wg}$ : berat gonad $(\mathrm{g})$

$\mathrm{W}$ : berat ikan tanpa gonad $(\mathrm{g})$

\section{HASILDAN BAHASAN \\ Hasil}

\section{Hubungan Panjang Berat}

Hubungan panjang berat ikan kembung lelaki jantan pada (Gambar 3) dinyatakan dalam persamaan $\mathrm{W}=0,0052 \mathrm{~L}^{3,2657}$ dengan koefisien determinasi 0,912 sedang untuk jenis ikan betina adalah $\mathrm{W}=0,0019 \mathrm{~L}^{3,5992}$ dengan koefisien determinasi 0,961 . Setelah dilakukan uji lanjutan (uji $\mathrm{F}$ ) diperoleh hasil $\mathrm{F}_{\text {hitung }} 2.582,440$ dan $\mathrm{F}_{\text {tabel }}$ 3,879 untuk ikan jantan dan $\mathrm{F}_{\text {hitung }} 912,094$ dan $\mathrm{F}_{\text {tabel }} 4,105$ untuk ikan betina. Hasil uji t menunjukkan nilai $t_{\text {hitung }} 65,494$ dan $\mathrm{t}_{\text {tabel }} 1,969$ untuk ikan jantan dan $\mathrm{t}_{\text {hitung }} 31,401$ dan $\mathrm{t}_{\text {tabel }}$ 2,024 untuk ikan betina.

\section{Nisbah Kelamin}

Selama penelitian dilakukan pada bulan Februari-April 2019 diperoleh nilai perbandingan antara ikan kembung jantan dan betina seperti disajikan pada Tabel 1 berikut.

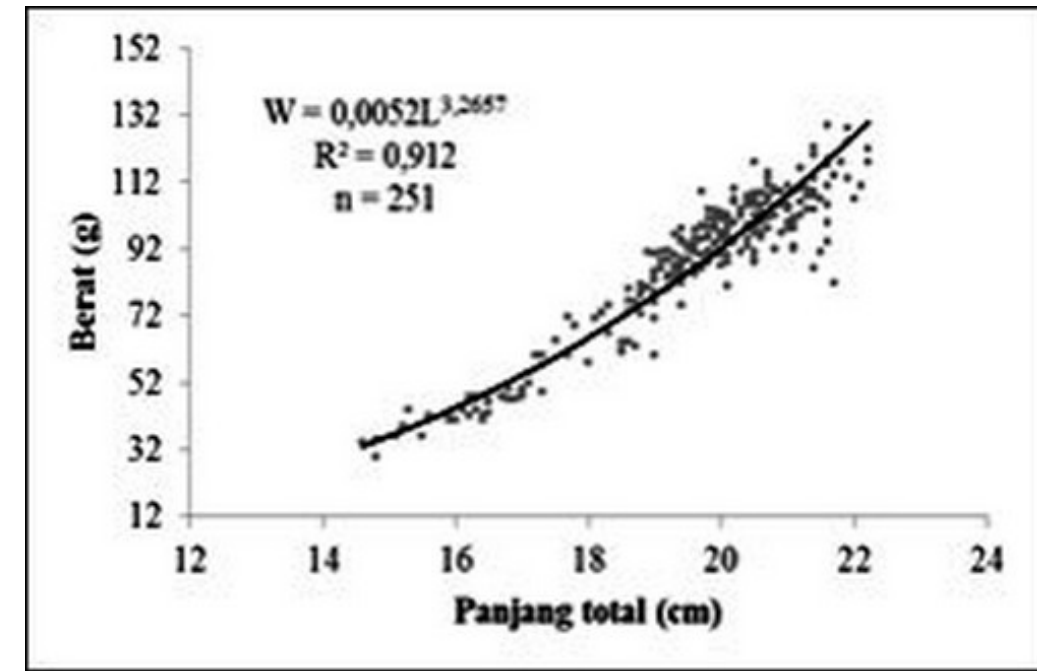

Gambar 3. Hubungan panjang berat ikan kembung lelaki jantan tahun 2018. Figure 3. Length weight relationship of male indian mackerel in 2018.

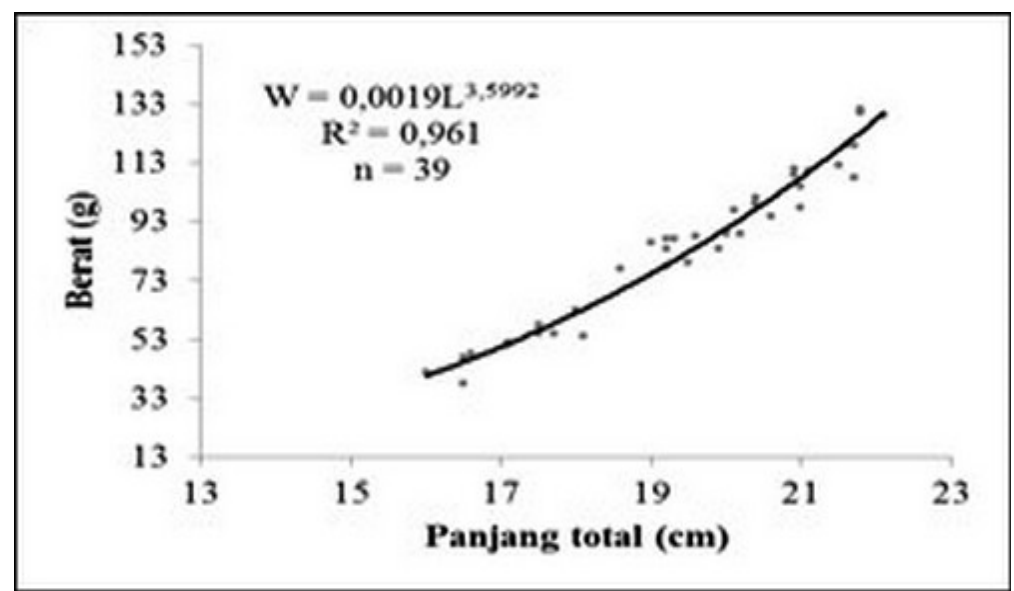

Gambar 4.

Hubungan panjang berat ikan kembung lelaki betina. tahun 2018 .

Figure 4.

Length weight relationship of female indian mackerel in 2018. 
Tabel 1. Nisbah kelamin dan uji statistik ikan kembung lelaki pada tahun 2018

Table 1. $\quad$ Ratio sex and chi-square test of indian mackerel in 2018

\begin{tabular}{|c|c|c|c|c|c|c|c|}
\hline \multirow{2}{*}{$\begin{array}{c}\text { Periode } \\
\text { Sampling }\end{array}$} & \multirow{2}{*}{$\mathbf{N}$} & \multicolumn{2}{|c|}{ Jumlah } & \multirow{2}{*}{$\begin{array}{c}\text { Tak } \\
\text { teridentifikasi }\end{array}$} & \multirow{2}{*}{$\begin{array}{c}\text { Nisbah } \\
\text { Kelamin }\end{array}$} & \multirow{2}{*}{$\begin{array}{c}\text { Nilai } \\
\text { Uji }\left(\mathbf{X}^{2}\right)\end{array}$} & \multirow{2}{*}{ Hasil Uji ( $\left.\mathbf{X}^{2}\right)$} \\
\hline & & Jantan & Betina & & & & \\
\hline 1 & 100 & 87 & 5 & 8 & $17,4: 1$ & 73,09 & Tak Seimbang \\
\hline 2 & 100 & 55 & 18 & 27 & $3,05: 1$ & 18,75 & Tak Seimbang \\
\hline 3 & 100 & 49 & 4 & 47 & 12,25: 1 & 38,21 & Tak Seimbang \\
\hline 4 & 100 & 61 & 12 & 27 & $5,08: 1$ & 32,89 & Tak Seimbang \\
\hline Total & 400 & 252 & 39 & 109 & $6,46: 1$ & 155,91 & Tak Seimbang \\
\hline \multicolumn{8}{|c|}{$\begin{array}{l}\text { Pada tabel } 1 \text { tercatat ikan yang tidak teridentifikasi jenis } \\
\text { kelaminnya sebanyak } 109 \text { ekor. Hal ini karena pada ukuran } \\
\text { tersebut gonad ikan belum berkembang (sangat kecil), } \\
\text { ketika dilihat secara visual belum dapat teridentifikasi jenis } \\
\text { kelaminnya. Hasil uji Chi-square diperoleh rasio jantan }\end{array}$} \\
\hline
\end{tabular}

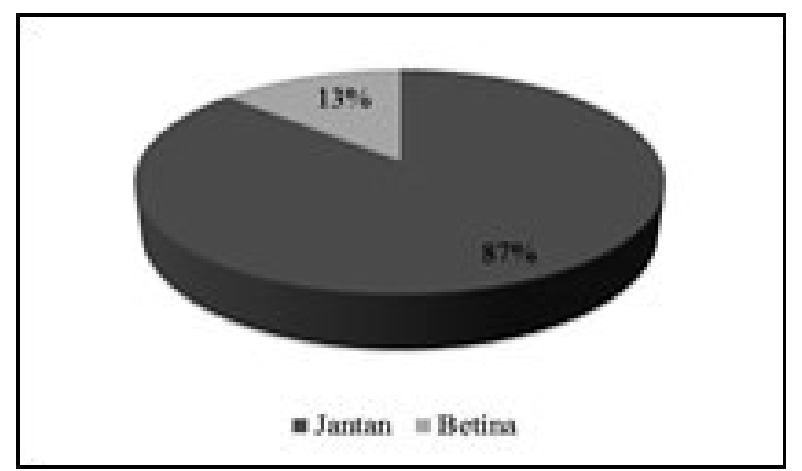

Gambar 5. Rasio kelamin ikan kembung lelaki pada tahun 2018.

Figure 5. Ratio sex of indian mackerel in 2018.

\section{Tingkat Kematangan Gonad}

Untuk mengetahui tingkat kematangan gonad ikan kembung lelaki telah dilakukan 2 cara pengamatan yantu secara morfologi/visual dan histologi/dengan mikroskopik. Hasil pengamatan secara morfologi disampaikan pada Taeblel 2 dan 3 berikut.

Tabel 2. Tingkat kematangan gonad ikan kembung lelaki (jantan) pada Februari-April 2018

Table 2. Gonad maturity level of indian mackerel (male) during February-April 2018

\begin{tabular}{rrrrr}
\hline TKG & TL $(\mathbf{c m})$ & W $(\mathbf{g})$ & $\mathbf{n}$ & GSI \\
\hline 0 & 15,9 & 41 & 1 & 0 \\
1 & $14,6-22,1$ & 78,84 & 123 & 0,39 \\
2 & $16,3-22,2$ & 90,91 & 38 & 0,99 \\
3 & $18,3-21,6$ & 97,88 & 46 & 3,09 \\
4 & $19-22,2$ & 100,10 & 43 & 6,32 \\
5 & 21,1 & 109 & 1 & 5,97 \\
\hline
\end{tabular}

Tabel 3. Tingkat kematangan gonad ikan kembung lelaki (betina) pada Februari-April 2018

Table 3. Gonad maturity level of indian mackerel (female) during February-April 2018

\begin{tabular}{rrrrr}
\hline TKG & TL $(\mathbf{c m})$ & W $(\mathbf{g})$ & $\mathbf{N}$ & GSI \\
\hline 1 & $16-20,6$ & 69,12 & 20 & 0,21 \\
2 & $17,1-21,7$ & 86,97 & 7 & 0,32 \\
3 & $19,2-21,6$ & 99,47 & 4 & 2,78 \\
4 & $20,9-22,1$ & 118,34 & 7 & 3,07 \\
5 & 20,9 & 111 & 1 & 2,56 \\
\hline
\end{tabular}


Tingkat kematangan gonad ikan kembung lelaki (jantan) yang diperoleh selama penelitian didominasi oleh TKG I dengan kisaran panjang 14,6-22,1 cmTL dengan jumlah 123 ekor. Sama halnya dengan tingkat kematangan gonad ikan kembung lelaki (betina) didominasi oleh TKG I dengan kisaran panjang 16-20,6 cmTL dengan jumlah 20 ekor (Gambar 6).
Selanjutnya hasil pengamatan tingkat kematangan gonad yang lebih teliti secara histologi disampaikan pada Tabel 4.

\section{Pengamatan Telur Ikan}

Adapun hasil pengamatan terhadap diameter telur ikan disampaikan pada Tabel 5 berikut ini.

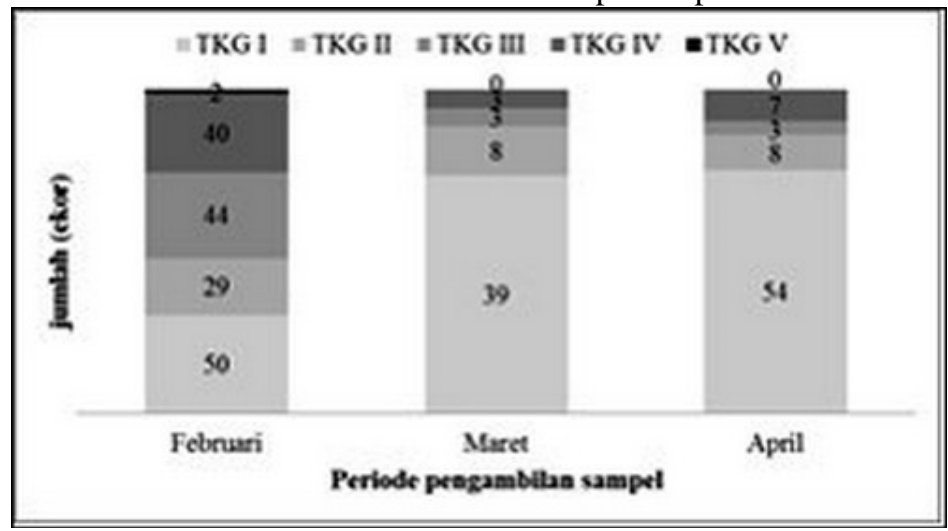

Gambar 6. Tingkat kematangan gonad ikan kembung lelaki (jantan\&betina) tiap bulan.

Figure 6. Gonad maturity level of indian mackerel (male \&female) every month.

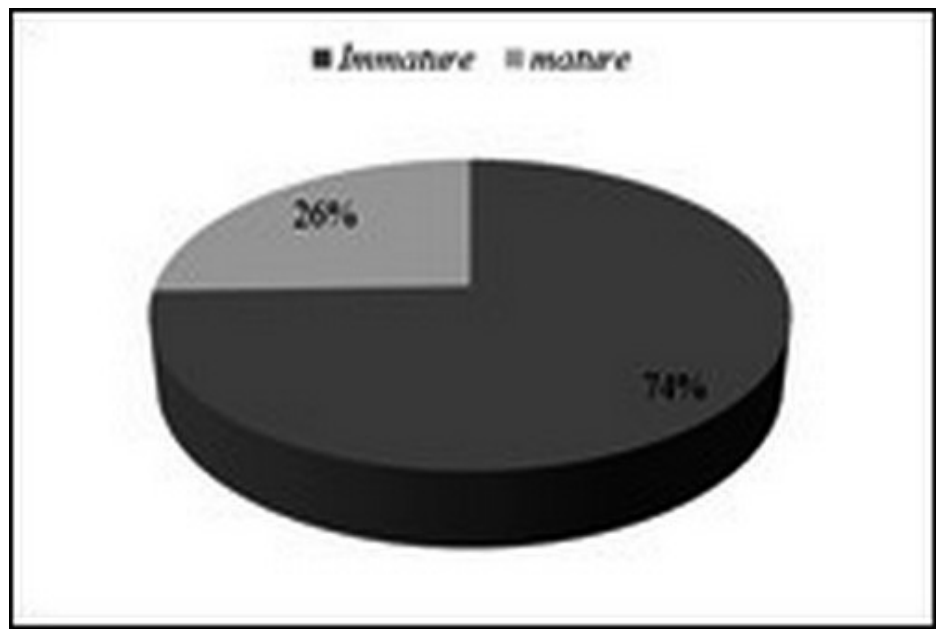

Gambar7. Persentase kematangan gonad ikan kembung lelaki keseluruhan.

Figure 7. Percentage all gonad maturity level of indian mackerel (male and female).

Tabel 4. Hasil analisis tingkat kematangan gonad ikan betina secara histologi

Table 4. Result of analysis female fish gonad maturity level on histology

\begin{tabular}{|c|c|c|c|c|c|c|}
\hline \multirow{2}{*}{ Kode } & \multicolumn{2}{|c|}{ Proporsi (\%) } & \multirow{2}{*}{$\begin{array}{c}\text { TKG } \\
\text { (Histologi) }\end{array}$} & \multirow{2}{*}{$\begin{array}{c}\text { TKG } \\
\text { (Morfologi) }\end{array}$} & \multirow{2}{*}{$\begin{array}{c}\text { Jumlah } \\
\text { telur } \\
(\mathbf{N})\end{array}$} & \multirow{2}{*}{ GSI } \\
\hline & $\begin{array}{c}\text { Advanced } \\
\text { yolked }\end{array}$ & $\begin{array}{c}\text { Migratory } \\
\text { nucleus }\end{array}$ & & & & \\
\hline RK_004 & $63 \%$ & $37 \%$ & 3 & 4 & 2.498 & 4,645 \\
\hline RK_028 & $24 \%$ & $76 \%$ & 4 & 4 & 2.402 & 5,121 \\
\hline RK_131 & $43 \%$ & $57 \%$ & 4 & 3 & 1.462 & 1,475 \\
\hline RK_150 & $10 \%$ & $90 \%$ & 4 & 5 & 2.629 & 2,559 \\
\hline RK_154 & $41 \%$ & $59 \%$ & 4 & 3 & 2.419 & 2,686 \\
\hline RK_156 & $30 \%$ & $70 \%$ & 4 & 3 & 2.510 & 1,047 \\
\hline RK_160 & $6 \%$ & $94 \%$ & 4 & 4 & 2.344 & 2,510 \\
\hline RK_181 & $28 \%$ & $72 \%$ & 4 & 4 & 3.148 & 2,648 \\
\hline
\end{tabular}




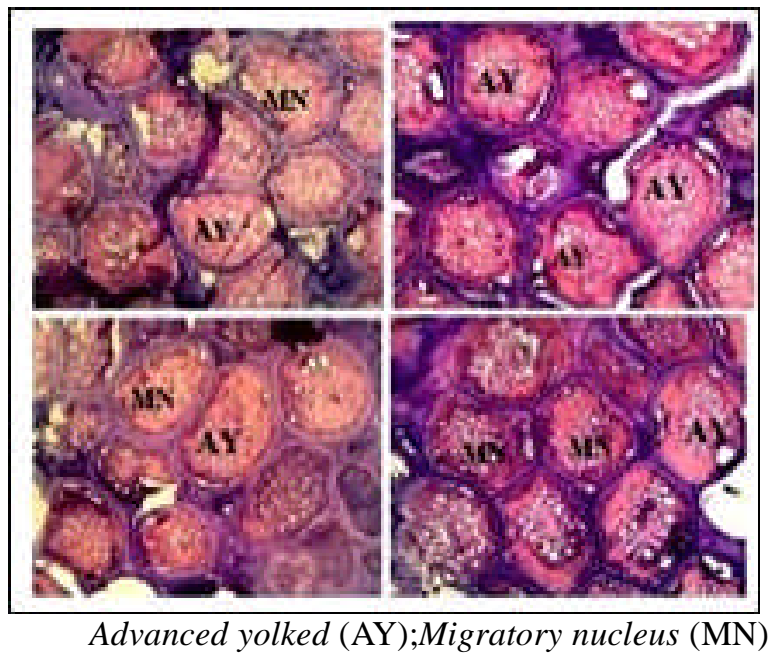

Gambar 8. Hasil pengamatan histologi gonad betina ikan kembung lelaki.

Figure 8. Results observation histology gonad female of indian mackerel.

Tabel 5. Diameter telur $(\mu \mathrm{m})$ ikan kembung lelaki

Table 5. Diameter of egg (ìm) indian mackerel

\begin{tabular}{|c|c|c|c|}
\hline \multirow{2}{*}{ Kode } & \multirow{2}{*}{ Periode Sampling } & \multicolumn{2}{|c|}{ TKG } \\
\hline & & III & IV \\
\hline RK_004 & 1 & 308,59 & 287,99 \\
\hline RK_028 & 1 & 280,91 & 315,31 \\
\hline RK_131 & 2 & 314,74 & 311,47 \\
\hline RK_150 & 2 & 286,84 & 296,82 \\
\hline RK_154 & 2 & 290,13 & 301,56 \\
\hline RK_156 & 2 & 310,29 & 305,52 \\
\hline RK_160 & 2 & 0,00 & 305,32 \\
\hline RK_181 & 2 & 285,94 & 307,11 \\
\hline \multirow{3}{*}{\multicolumn{2}{|c|}{$\begin{array}{c}\text { Mean } \\
\text { Min } \\
\text { Max }\end{array}$}} & 296,78 & 303,89 \\
\hline & & 280,91 & 287,99 \\
\hline & & 314,74 & $\mathbf{3 1 5 , 3 1}$ \\
\hline
\end{tabular}

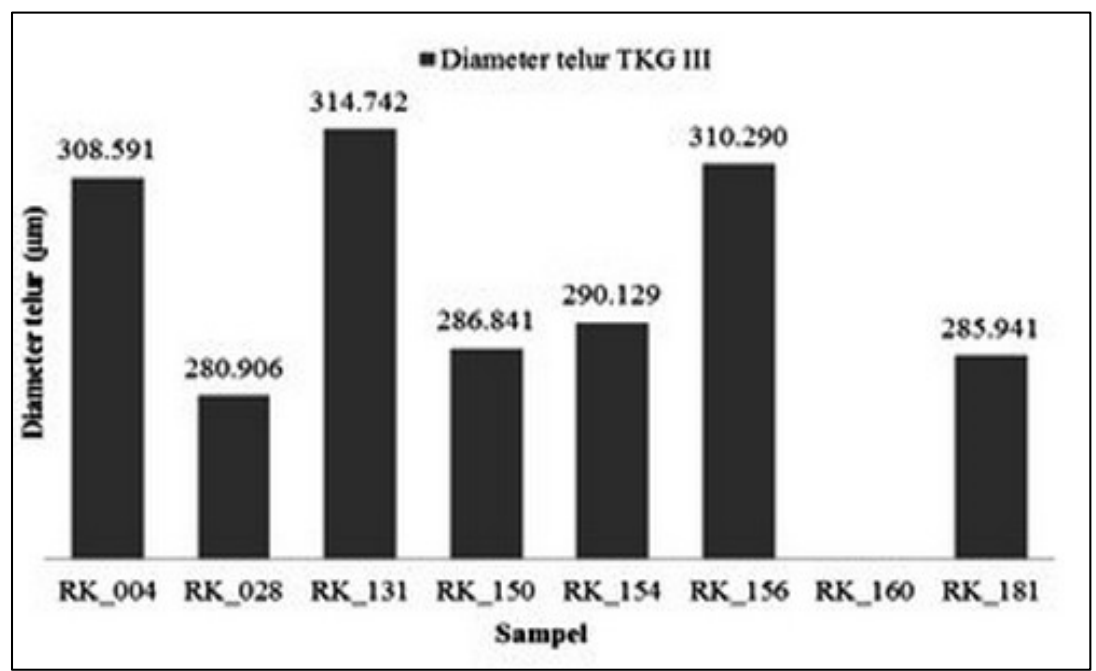

Gambar 9. Sebaran diameter telur TKG III.

Figure 9. Distribution of egg diameter GML III. 


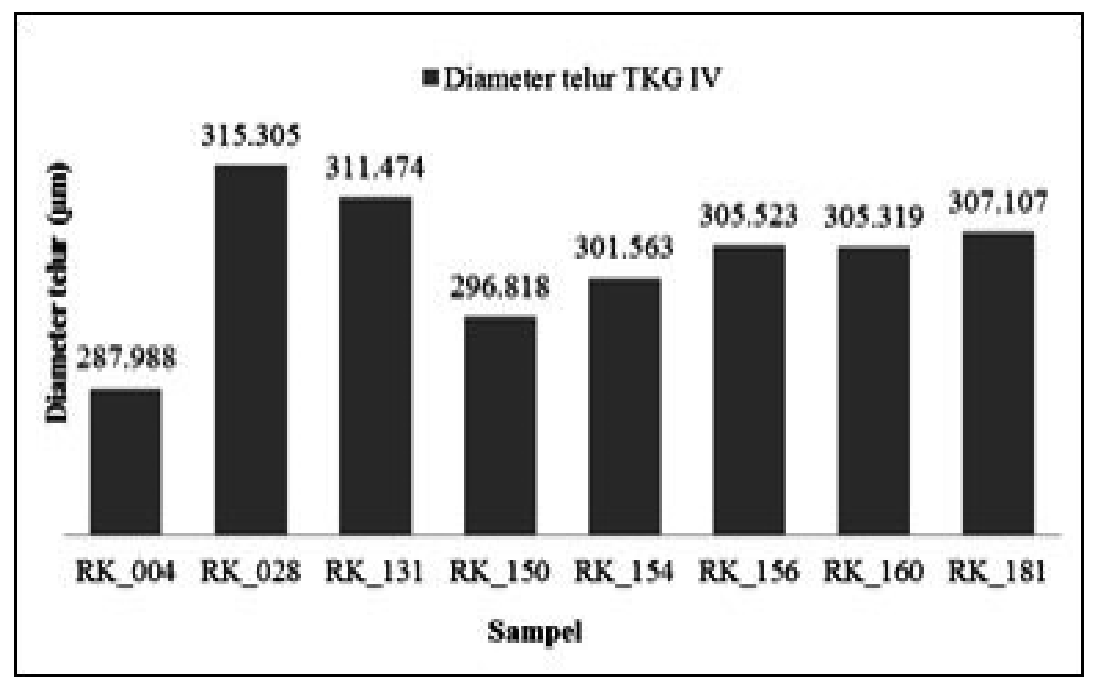

Gambar 10. Sebaran diameter telur TKG IV.

Figure 10. Distribution of egg diameter GMLIV.

\section{Fekunditas (jumlah telur)}

Nilai fekunditas yang diperoleh dari 8 sampel yang digunakan berkisar 4.863,96-28.255.32 butir. Ikan yang dapat dihitung fekunditasnya adalah ikan yang telah memasuki TKG III-V, karena pada tingkatan tersebut butiran telur sudah terlihat jelas dan dapat dibedakan.

Tabel 6. Fekunditas ikan kembung lelaki

Table 6. Fecundity of indian mackerel

\section{Indeks Kematangan Gonad}

Nilai IKG tertinggi ikan kembung lelaki yang diperoleh selama penelitian terdapat pada bulan Maret yaitu sebesar $57,98 \%$ dengan panjang $20,1 \mathrm{cmTL}$, berat 100 gram dan berat gonad $36,7 \mathrm{~g}$ sedangkan yang terendah terjadi pada bulan April yaitu 6,32\% dengan panjang $19.8 \mathrm{cmTL}$, berat $96 \mathrm{~g}$ dan berat gonad 5,71 g.

\begin{tabular}{rrrrrrrr}
\hline Kode & Periode sampling & TL & W & Wg & Ws & $\begin{array}{c}\text { Jumlah } \\
\text { telur } \\
\text { (cm) }\end{array}$ & \multicolumn{2}{c}{ (g) } & & $\begin{array}{c}\text { Fekunditas } \\
\text { (butir) }\end{array}$ \\
\hline RK_004 & 1 & 21,8 & 129,95 & 5,77 & 0,51 & 2498 & 28.255 .32 \\
RK_028 & 1 & 22,1 & 129,2 & 6,29 & 0,54 & 2402 & $27.997,09$ \\
RK_131 & 2 & 21,6 & 119 & 1,73 & 0,52 & 1462 & $4.863,96$ \\
RK_150 & 2 & 20,9 & 111 & 2,77 & 0,53 & 2629 & $13.740,25$ \\
RK_154 & 2 & 20,4 & 99 & 2,59 & 0,52 & 2419 & $12.048,48$ \\
RK_156 & 2 & 21,1 & 110 & 1,14 & 0,54 & 2510 & $5.298,89$ \\
RK_160 & 2 & 21 & 98 & 2,4 & 0,50 & 2344 & $11.251,20$ \\
RK_181 & 2 & 21,7 & 119 & 3,07 & 0,55 & 3148 & $17.571,56$ \\
\hline
\end{tabular}

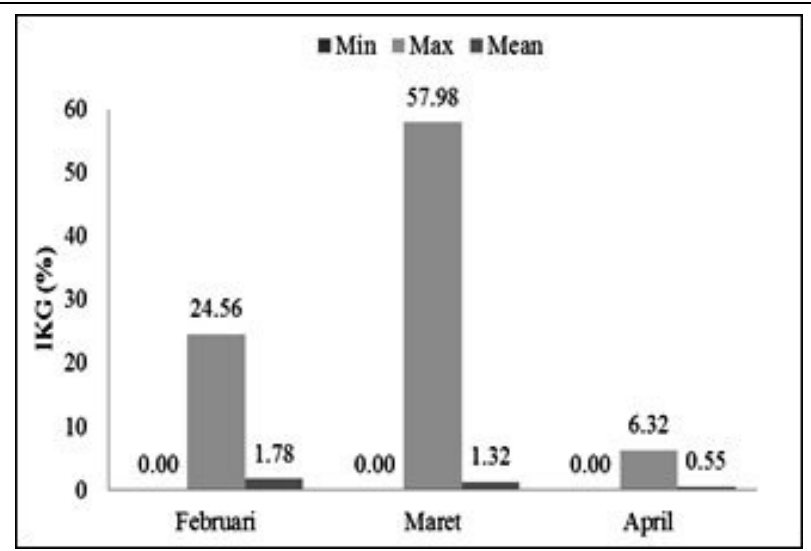

Gambar 11. Indeks kematangan gonad ikan kembung lelaki.

Figure 11. Gonad somatic index of indian mackerel. 


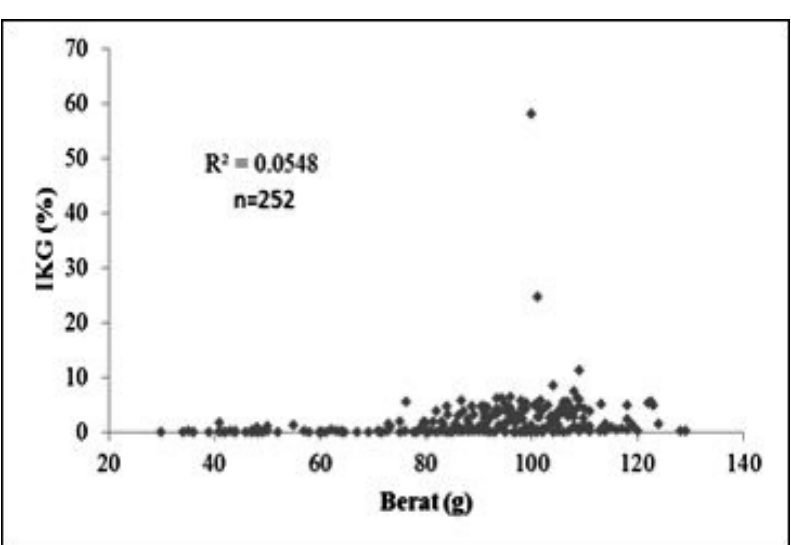

Gambar 12. Hubungan berat dengan indek kematangan gonad ikan kembung lelaki (jantan).

Figure 12. Weight-gonad somatic index relationship of indian mackerel (male).

\section{Bahasan}

Dari hubungan panjang berat $R$. kanagurta jantan diperoleh persamaan $\mathrm{W}=0,0052 \mathrm{~L}^{3,2657}$ dan betina adalah $\mathrm{W}=0,0019 \mathrm{~L}^{3,5992}$. Hasil uji $\mathrm{F}$ yaitu $\mathrm{F}_{\text {hitung }}>\mathrm{F}_{\text {tabel }}$ untuk kedua jenis R.kanagurta (tolak $\mathrm{H} 0$ terima $\mathrm{H} 1$ ) panjang berpengaruh nyata terhadap berat. Hasil uji $T$ yaitu $\mathrm{T}_{\text {hitung }}>\mathrm{T}_{\text {tabel }}$ untuk kedua jenis R. kanagurta (tolak $\mathrm{H} 0$ terima H1) dimana b“"3 (Allometrik). Nilai b ikan kembung jantan sebesar 3,2657 dan ikan kembung betina sebesar 3,5992. Dimana nilai $b>3$ yang merupakan pertumbuhan allometrik positif (pertumbuhan berat lebih cepat daripada panjang). Hal ini sesuai dengan hasil penelitian Nasution (2014), bahwa hasil analisis hubungan panjang berat ikan kembung lelaki mempunyai nilai b 3,24 (b>3), yang mengindikasikan pertumbuhan berat lebih dominan daripada pertumbuhan panjang (allometrik positif).

Perbedaan rasio kelamin yang signifikan/menyimpang dari nilai satu, disebabkan oleh adanya selektivitas alat tangkap atas jenis kelamin (Zamroni \& Suwarso, 2011). Perbandingan kelamin dapat berubah menjelang dan selama pemijahan. Ketika melakukan ruaya pemijahan, populasi ikan didominasi oleh ikan jantan, kemudian menjelang pemijahan populasi ikan jantan dan betina dalam keadaan seimbang, lalu didominasi oleh ikan betina (Sulistiono et al., 2001). Hal ini sesuai dengan hasil penelitian Zamroni \& Suwarso (2011), yang menyatakan bahwa nisbah kelamin ikan R.kanagurta terjadi perbedaan yang cukup signifikan antara jantan dan betina 1,77:1 (64\% $: 36 \%)$.

Hasil analisis TKG secara morfologi ikan kembung lelaki (jantan \& betina), seluruh sampel (400 ekor) diperoleh TKG yang dominan yaitu TKG I Dara berkembang (immature). Dapat dikatakan bahwa ikan kembung lelaki yang didaratkan TPI Mayangan Probolinggo pada saat penelitian berlangsung (Februari-April 2018), termasuk

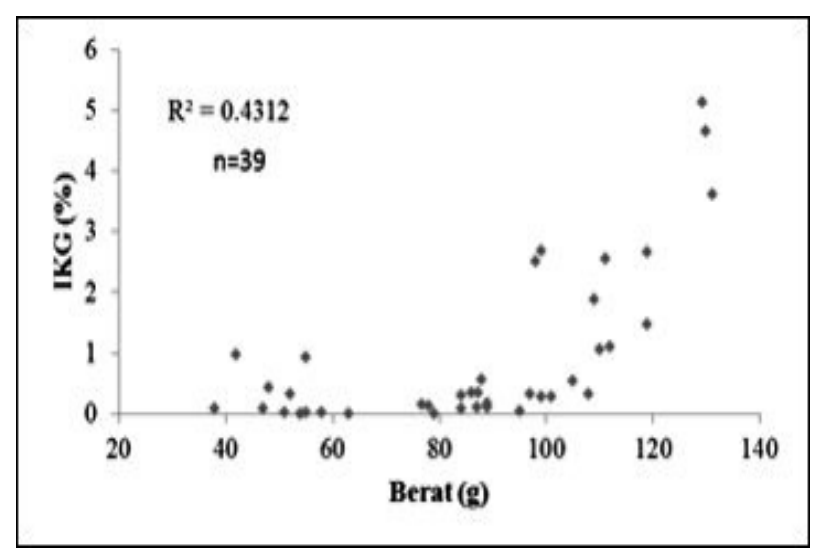

Gambar 13. Hubungan berat dengan indek kematangan gonad ikan kembung lelaki (betina).

Figure 13. Weight-gonad somatic index relationship of indian mackerel (female).

dalam kategori belum matang gonad/. Hal ini sesuai dengan penelitian Syahriani et al. (2015) yang menyebutkan tingkat kematangan gonad ikan kembung lelaki selama penelitian paling dominan adalah TKG I dan yang paling sedikit adalah TKG V.

Pada (Gambar 7) menunjukkan bahwa ikan masih dalam taraf perkembangan gonad, ditunjukkan dengan $26 \%$ (mature) dan 74\% (immature). Hasil uji Chi-Square yaitu $\mathrm{X}_{\text {hitung }}^{2} 96,04$ dan $\mathrm{X}_{\text {tabel }}^{2} 3,84\left(\mathrm{X}_{\text {hitung }}^{2}>\mathrm{X}_{\text {tabel })}\right.$ yang berarti immature " mature (tidak seimbang). Hal ini sesuai dengan hasil penelitian Hidayat (2014), bahwa tingkat kematangan gonad ikan kembung lelaki yang diperoleh selama penelitian tidak seimbang, immature $(61 \%)$ dan mature (39\%). Hanya sedikit ikan yang matang sexual (mature dan spent) dalam tangkapan purse seine. Kelompok ikan tersebut (tahap late maturing dan early mature), diketahui sebagai spawning stock, diduga keluar dari daerah penangkapan purse seine dan bermigrasi menuju spawning ground. Ketika migrasi diduga terjadi perkembangan gonad ke arah makin matang (fully mature). Puncak pemijahan terefleksi pada muncul ikan ukuran kecil (ikan muda) sebagai awal recruitment pada perikanan purse seine yang muncul beberapa bulan (6-8 bulan) setelah puncak pemijahan (Suwarso et al., 2008).

Pada (Tabel 4) terlihat bahwa gonad betina ikan kembung lelaki terdiri dari dua fase, Advanced yolked (TKG III) dan Migratory nucleus (TKG IV). Fase Advanced yolked ditandai dengan Jumlah dan ukuran butiran kuning telur semakin bertambah dan nampak jelas di seluruh area sel telur. Oil droplet mulai terlihat didalam sitoplasma, inti sel terletak di tengah sel telur dan zona radiata melebar. Pada fase Migratory nucleus mempunyai ciri-ciri Oil droplet semakin banyak dan menyebar dari sekitar inti sel sampai ke pinggiran sel telur. Inti sel mulai bermigrasi menuju tepi sel telur dan biasanya tergantikan oleh oil droplet. Hasil penelitian Hasibuan (2015) menyebutkan 
secara histologi gonad ikan betina menunjukkan TKG I didominasi oogonia dan inti sel, TKG II terdapat oosit primer dan oosit sekunder, TKG III didominasi oosit tahap vitogenesis 1 dan 2, TKG IV didominasi oosit,tahap vitelogenesis 2 dan 3 dengan ootid berkembang yang siap untuk memijah dan TKG V didominasi oosit atresi. Nasution (2014) menyebutkan ditemukannya ikan yang sudah mencapai TKG 3 dan 4 merupakan indikator adanya ikan yang memijah pada perairan tersebut.

Dari sampel yang digunakan, diperoleh kisaran diameter telur TKG III 280,91-314,74 $\mu$ m dengan rerata 296,78 $\mu$ m dan pada TKG IV 287,99-315,31 $\mu$ m dengan rerata $303,89 \mu \mathrm{m}$. Jika dilihat dari ukuran diameter telurnya tidak ada perbedaan ekstrim antara keduanya, tetapi dari karakteristiknya menunjukkan pernbedaan komponen pada TKG III dan TKG IV. Hal ini tidak sesuai dengan hasil penelitian menurut Farley \& Davis (1999) yang menyebutkan pada keadaan TKG III Permulaan Matang (Advanced yolked stage) mempunyai diameter telur antara 300-700 $\mu \mathrm{m}$ dan pada kondisi TKG IV Hampir Matang (Migratory nucleus stage) mempunyai kisaran diameter telur 550-800 $\mu \mathrm{m}$. Hal ini membuktikan bahwa ukuran diameter telur tidak bisa dijadikan sebagai acuan tunggal dalam penentuan TKG. Karena terkadang ada sebagian telur dengan diameter yang tergolong kecil tetapi jika diamati secara histologi mempunyai komposisi sel telur yang menunjukkan telah memasuki TKG tinggi.

Hasil fekunditas dari 8 sampel gonad ikan kembung lelaki tersaji pada (Tabel 6) ukuran ikan yang dijadikan sampel antara 20,4-22,1 cmTL dan berat antara 98-129,95 g. Nilai fekunditas yang diperoleh 4.863,96-28.255,32 butir telur. Hasil penelitian Permatasari (2016) menyebutkan fekunditas ikan kembung lelaki sebanyak 5.001-96.530 butir, semakin banyak telur yang dikeluarkan maka potensi reproduksi ikan kembung lelaki semakin tinggi. Besar kecilnya nilai fekunditas dipengaruhi oleh beberapa hal yaitu komposisi umur, persediaan makanan, kepadatan populasi, suhu perairan, oksigen terlarut dan faktor fisiologi tubuh (Nikolsky, 1969).

Pada (Gambar 11) diduga ikan kembung lelaki mulai melakukan pemijahan pada saat penelitian berlangsung. Dibuktikan dengan nilai rerata IKG yang semakin menurun tiap bulannya. Dimulai pada Februari dengan nilai rerata 1,78 dan selanjutnya mengalami penuruan secaara bertahap hingga April dengan nilai 0,55. Rendahnya nilai IKG dikarenakan kelompok ikan yang matang gonad tidak berada di daerah penangkapan (fishing ground), diduga bermigrasi ke daerah pemijahan (spawning ground) dan daerah penangkapan juga merupakan daerah untuk mencari makan (feeding food) serta pertumbuhan bagi ikan ini (Zamroni et al., 2008). Semakin tinggi perkembangan gonad maka perbandingan antara berat tubuh dan gonad semakin besar yang diperlihatkan dengan nilai IKG yang besar, semakin besar nilai IKG maka dapat dijadikan sebagai salah satu indikator semakin dekatnya waktu pemijahan (Faizah, 2010).

Pada (Gambar 12) (Gambar 13) terlihat bahwa nilai IKG tidak selalu berkaian dengan berat ikan kembung lelaki (jantan \& betina). Terlihat sebaran nilai IKG tidak terdistribusi merata pada berat 20-140 g. Hal ini menunjukkan bahwa nilai IKG tidak selalu berkaitan dengan berat ikan. Hal ini sesuai dengan penelitian Sembiring et al, (2014) yang menyebutkan nilai IKG tidak selalu berkaitan dengan berat ikan. Serta hasil penelitian Andamari et al. (2012) menyebutkan Ikan yang lebih berat tidak selalu mempunyai nilai IKG yang besar juga. Contoh ikan yang bobotnya hampir $80 \mathrm{~kg}$ hanya mempunyai nilai IKG 0,4 sementara ikan yang beratnya hanya $45 \mathrm{~kg}$ mempunyai IKG 2. Nilai IKG lebih ditentukan dengan besarnya gonad dan tingkat kematangannya.

\section{KESIMPULAN}

Ikan kembung lelaki di Selat Madura memiliki pertumbuhan berat yang lebih cepat daripada pertumbuhan panjang dan didominasi oleh jantan dengan rasio $6: 1$. Tingkat kematangan gonad ikan kembung lelaki (Februari-April 2018) didominasi oleh TKG I sebanyak 143 ekor $(35,75 \%)$. Diameter telur pada TKG III dan TKG IV mempunyai nilai yang hampir sama tetapi mempunyai komponen yang berbeda. Nilai fekunditas berkisar 4.863,96-28.255,32 butir. Nilai IKG yang diperoleh selama penelitian mengalami penuruan tiap bulannya, artinya ikan kembung lelaki mulai melakukan pemijahan ketika penelitian berlangsung. Nilai IKG maksimun tercapai pada bulan Maret. Hubungan berat dengan IKG mempunyai pengaruh yang signifikan tetapi tingkat keeratannya rendah. Analisa TKG dengan metode histologi adalah akurat namun kurang efisien dari segi waktu dan biaya.

Rekomendasi pengelolaan sumberdaya ikan kembung lelaki dapat berupa peninjauan tingkat upaya penangkapan. Perlunya pembatasan upaya serta manajemen waktu dan lokasi penangkapan ikan kembung di perairan Selat Madura, seperti mengurangi upaya penangkapan ketika puncak musim pemijahan dan atau pembatasan area penangkapan di area yang diduga menjadi area spawning. Perlunya pembatasan penentuan kuota hasil tangkapan, serta pengawasan selektifitas alat tangkap yang digunakan.

\section{PERSANTUNAN}

Penulis mengucapkan terima kasih pada program studi Pemanfaatan Sumberdaya Perikanan Fakultas Perikanan dan Ilmu Kelautan Universitas Brawijaya Malang, Loka Riset Perikanan Tuna, Denpasar-Bali yang telah menjadi bagian penulisan artikel ini, Laboratorium Fakultas SAINS 
Universitas Islam Negeri Maulana Malik Ibrahim Malang (M. Basyaruddin) yang telah membantu dalam preparasi histologi gonad, serta pemangku kepentingan pengelolaan perikanan di Mayangan, Probolinggo, Jawa Timur yang telah memberikan informasi terkait topik penelitian ini.

\section{DAFTAR PUSTAKA}

Andamari, R., Hutapea, J.H., \& Prisantoso, B.I. (2012). Aspek reproduksi ikan tuna sirip kuning (Thunnus albacares). Jurnal Ilmu dan Teknologi Kelautan Tropis, 4(1):89-96. Balai Besar Riset Perikanan Budidaya Laut Gondol, Singaraja-Bali. DOI: https://doi.org/ 10.29244/jitkt.v4i1.7809

Faizah, R. (2010). Biologi Reproduksi Ikan Tuna Mata Besar (Thunnus obesus) di Perairan Samudera Hindia. Tesis. Institut Pertanian Bogor. Bogor.

Farley, J. H., \& Davis, T. L. O. (1999). Size at first maturity and recruitment into egg production of southern bluefin tuna. CSIRO Marine Research: Australia

Hasibuan, J.S. (2015). Hubungan panjang bobot dan reproduksi ikan kembung lelaki (Rastrelliger kanagurta) di Perairan Selat Malaka Tanjung Beringin Serdang Bedagai Sumatera Utara. Skripsi. Program studi Manajemen Sumberdaya Perairan. Fakultas Pertanian. Universitas Sumatera Utara. Medan.

Hidayat, I. R. (2014). Analisis tingkat kematangan gonad dan fekunditas ikan kembung (Restrelliger $\mathrm{sp}$ ) di Perairan Aceh Barat. Skripsi. Fakultas Perikanan Dan Ilmu Kelautan Universitas Teuku Umar Meulaboh. Aceh Barat.

IOTC (Indian Ocean Tuna Commission). (2010). Reproductive biology of yellowfin tuna (Thunnus albacares) in the Western and Central Indian Ocean. WPTT-48

Jatmiko, I., Hartaty, H., \& Bahtiar, A. (2015). Biologi reproduksi ikan cakalang (Katsuwonus pelamis) di Samudra Hindia Bagian Timur. BAWAL. 7(2), 87-94. DOI: http://dx.doi.org/10.15578/bawal.7.2.2015.87-94

Kusmini, I. I., F. P. Putri., \& V. A. Prakoso. (2016). Bioreproduksi dan hubungan panjang berat terhadap fekunditas pada ikan lalawak (Barbonymus balleroides). Jurnal Riset Akuakultur, 11(4), 339-345. DOI: http://dx.doi.org/10.15578/jra.11.4.2016.339-345

Mujimin. (2005). Teknik pembuatan preparat histologi gonad. Buletin Teknik Litkayasa Akuakultur, 4(2), 1317. DOI: http://dx.doi.org/10.15578/blta.4.2.2005.13-17
Nasution, M.A. (2014). Pertumbuhan dan Reproduksi Ikan Kembung Lelaki (Rastrelliger kanagurta Cuvier 1817) di Teluk Pelabuhan Ratu. Tesis. Institut Pertanian Bogor. Bogor

Nikolsky.G.V. (1969). Theory of fish population dynamic as the biological background of rational exploitation and the management of fisheries resources (p. 323). Translate by Bradly, Oliver and Boyd

Permatasari, Z. (2016). Biologi reproduksi ikan kembung lelaki (Rastrelliger kanagurta, Cuvier 1817) di Perairan Selat sunda. Skripsi. Departemen Manajemen Sumberdaya Perairan.Fakultas Perikanan dan Ilmu Kelautan.Institut Pertanian Bogor. Bogor

Putri, D. U. (2012). Kinerja reproduksi ikan nila (Oreochromis niloticus) Pada Media Bioflok. Skripsi. FPIK Institut Pertanian Bogor. Bogor

Schaefer, K. M. (2001). Assessment of skipjack Tuna (Katsuwonus pelamis) Spawning Activity in The Eastern Pacific Ocean. Fish.Bull, (99), 343-350.

Schaefer, M. B \& C. J. Orange. (1956). Studies of The Sexual Development and Spawning of Yellowfin Tuna (Neothunnus macropterus) and Skipjack (Katsuwonus pelamis) in Three Areas of The Eastern Pacific Ocean by Examination of Gonads. Bull.Inter-American Tropical Tuna Commission (I-ATTC) 1(6).281-349.

Sembiring, S. B.M., Andamari, R., Muzaki, A., Wardana, I.K., Hutapea, J.H., \& Astuti, N.W.W. (2014). Perkembangan Gonad Ikan Kerapu Sunu (Plectropomus leopardus) yang Dipelihara dalam Keramba Jaring Apung. Jurnal Ilmu dan Teknologi Kelautan Tropis 6(1), 53-61. DOI: https://doi.org/ 10.29244/jitkt.v6i1.8627

Sparre, P., \& Venema, S. C. (1999). Introduction to tropical fish stock assessment.Part 1.Manual (Introduksi Pengkajian Stok Ikan Tropis.Buku 1.Manual). FAO Fisheries Technical Paper no.306/1 Rev 2. Diterjemahkan oleh Pusat penelitian dan Pengembangan Perikanan. Puslitbangkan. Jakarta

Sulistiono., Jannah, M.R., \& Ernawati, Y. (2001). Reproduksi Ikan Belanak (Mugil dussumieri) di Perairan Ujung Pangkah, Jawa Timur. Jurnal Iktiologi Indonesia, 1(2), 31 -37 ISSN 1693-0339.

Suwarso., A.Zamroni., \& Wudianto. (2008). Biologi Reproduksi dan Dugaan Musim Pemijahan Ikan Pelagis Kecil di Laut Cina Selatan. J.Lit.Perikan.Ind, 14(4), 379-391. DOI: http://dx.doi.org/10.15578/ jppi.14.4.2008.379-391 
Syahriani, J., Basyuni, M., \& Suryanti, A. (2015). Hubungan panjang bobot dan reproduksi ikan kembung lelaki Rastrelliger kanagurta (Cuvier, 1817) di Perairan Selat Malaka Tanjung Beringin serdang Bedagai Sumatra Utara. Jurnal aquacoastmarine 9(4).

Zamroni \& Suwarso. (2011). Studi Tentang Biologi Reproduksi Beberapa Spesies Ikan Pelagis Kecil di Perairan Laut Banda. BAWAL 3(5), 337-344. DOI: http:/ /dx.doi.org/10.15578/bawal.3.5.2011.337-344
Zamroni, A., Suwarso., \& N.A.Mukhlis. (2008). Biologi Reproduksi dan Genetic Populasi Ikan Kembung (Rastrelliger brachysoma, Famili Scombridae) di Pantai Utara Jawa. J.Lit.Perikan.Ind, 14(2), 215-226. DOI: http://dx.doi.org/10.15578/jppi.14.2.2008.215-226 
Lampiran 1. Hasil pengamatan gonad ikan kembung lelaki Appendix 1. The results of observation gonad indian mackerel

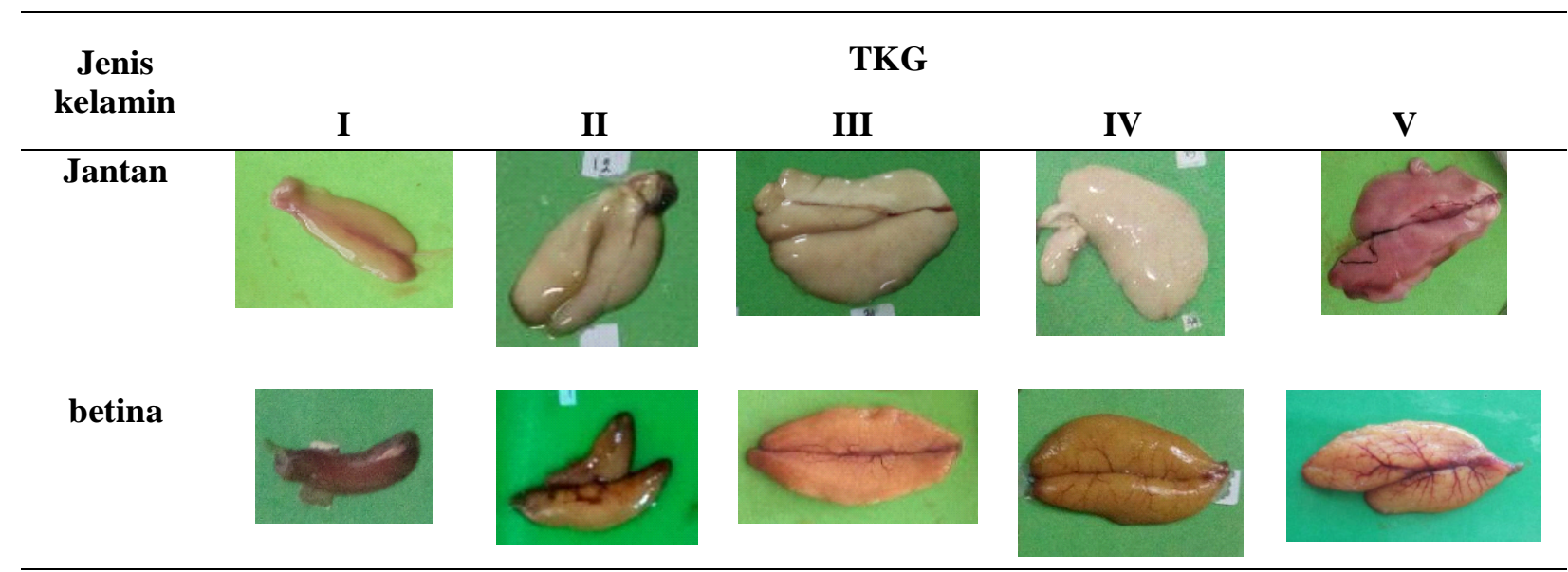

Lampiran 2. Penentuan TKG Ikan Betina secara Histologi menurut Farley \& Davis (1999)

Appendix 2. Histological determination GML of female fish by Farley \& Davis (1999)

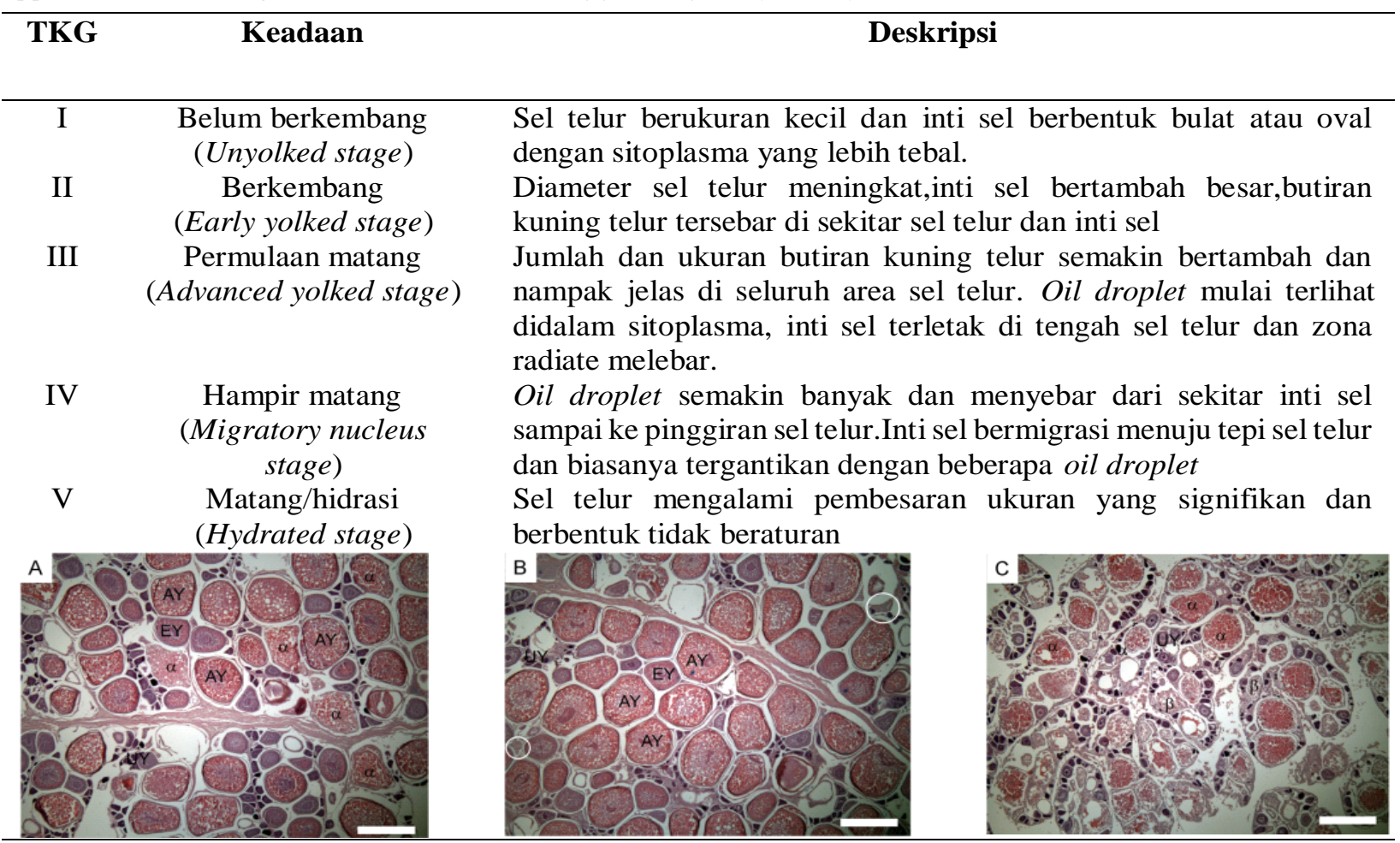


Lampiran 3. Penentuan TKG ikan betina secara morfologi Schaefer \& Orange (1956)

Appendix 3. Morphological determination GML offemale fish Schaefer \& Orange (1956)

\begin{tabular}{|c|c|c|}
\hline TKG & Keadaan & Deskripsi \\
\hline I & $\begin{array}{l}\text { Dara Berkembang } \\
\quad \text { (Immature) }\end{array}$ & $\begin{array}{l}\text { Gonad memanjang dan ramping, ovari jernih berwarna abu-abu sampai } \\
\text { kemerah-merahan, telur satu per satu dapat dilihat dengan kaca pembesar. }\end{array}$ \\
\hline II & $\begin{array}{l}\text { Perkembangan I } \\
\text { (Early maturing) }\end{array}$ & $\begin{array}{l}\text { Ovari membesar, berwarna kemerah-merahan dengan pembuluh kapiler, } \\
\text { bulatan telur belum dapat terlihat dengan mata telanjang, ovari mengisi } \\
\text { sekitar setengah ruang bawah. }\end{array}$ \\
\hline III & $\begin{array}{l}\text { Perkembangan II } \\
\text { (Late maturing) }\end{array}$ & $\begin{array}{l}\text { Ovari membesar dan membengkak, berwarna orange kemerah-merahan, } \\
\text { butiran telur sudah dapat terlihat dengan mata biasa, ovari mengisi } 2 / 3 \text { ruang } \\
\text { bawah. }\end{array}$ \\
\hline IV & Matang (Ripe) & $\begin{array}{l}\text { Ovari sangat membesar, butiran telur membesar dan berwarna jernih, dapat } \\
\text { keluar dari lumen dengan sedikit penekanan pada bagian perut, gonad } \\
\text { mengisi penuh ruang bawah. }\end{array}$ \\
\hline $\mathrm{V}$ & $\begin{array}{l}\text { Memijah } \\
\text { (Spawning) }\end{array}$ & $\begin{array}{l}\text { Termasuk yang memijah sekarang dan mijah sebelumnya, ovary sangat besar } \\
\text { dan lunak. Telur matang yang tertinggal dalam keadaan terserap, telur } \\
\text { berwarna jernih dan ada yang tertinggal dalam ovari. Telur akan keluar } \\
\text { dengan sedikit penekanan pada perut. }\end{array}$ \\
\hline \multicolumn{3}{|c|}{$\begin{array}{ll}\text { Lampiran 4. } & \text { Penentuan TKG Ikan Jantan secara Morfologi (Zamroni\&Suwarso, 2011) } \\
\text { Appendix 4. } & \text { Morphological determination GML of male fish (Zamroni\&Suwarso, 2011) }\end{array}$} \\
\hline TKG & Status & Deskripsi \\
\hline I & $\begin{array}{l}\text { Dara } \\
\text { (Immature) }\end{array}$ & $\begin{array}{l}\text { Ovary dan testis kecil padat, menempel dekat lubang anus, dan bentuk silindris. } \\
\text { Ovary berwarna kemerahan jernih, translucent; testis keputihan. Seringkali } \\
\text { tertutup lemak. GSI: } 0,11-2,69\end{array}$ \\
\hline II & $\begin{array}{l}\text { Perkembangan } \\
\text { (Maturing) }\end{array}$ & $\begin{array}{l}\text { Ovary dan testis ukuran sampai } 1 / 2 \text { panjang rongga badan. Ovary kemerahan } \\
\text { jernih, testis putih; kira-kira simetris. Butiran ova tidak nampak oleh mata } \\
\text { telanjang. GSI: } 0,28-4,75\end{array}$ \\
\hline III & $\begin{array}{l}\text { Pematangan } \\
\text { (Ripening) }\end{array}$ & $\begin{array}{l}\text { Ovary dan testis ukuran } 1 / 2-2 / 3 \text { panjang rongga badan. Ovary berwarna } \\
\text { kuning-kemerahan, terlihat jelas butiran-butiran telurnya; Nampak pembuluh } \\
\text { darah pada permukaannya; testis berwarna putih. Tidak ada telur } \\
\text { transparan/translucent. GSI: } 0,59-7,19\end{array}$ \\
\hline IV & $\begin{array}{l}\text { Matang } \\
\text { (Mature/ripe) }\end{array}$ & $\begin{array}{l}\text { Ovary dan testis besar ukuran } 2 / 3 \text { sampai memenuhi rongga badan. Ovary } \\
\text { berwarna orange-pink dengan banyak pembuluh darah, transparan; butiran ova } \\
\text { besar, ripe, dan translucent. Testis putih, lembek. GSI: } 2,59-11,24\end{array}$ \\
\hline V & $\begin{array}{l}\text { Mijah/salin } \\
\text { (Spent) }\end{array}$ & $\begin{array}{l}\text { Ovarium dan testis berukuran sampai } 1 / 2 \text { dari panjang rongga badan. Dinding- } \\
\text { dindingnya meluruh. Ovary berisi sisa hancuran buram dan telur yang matang, } \\
\text { gelap, atau transparan. Testis berwarna darah and lembek. GSI: } 0,53-7,73\end{array}$ \\
\hline
\end{tabular}

